ppi $201502 Z U 4645$

Esta publicación cientifica en formato digital es continuidad de la revista impresa ISSN-Versión Impresa 0798-1406 / ISSN-Versión on line 2542-3185Depósito legal pp

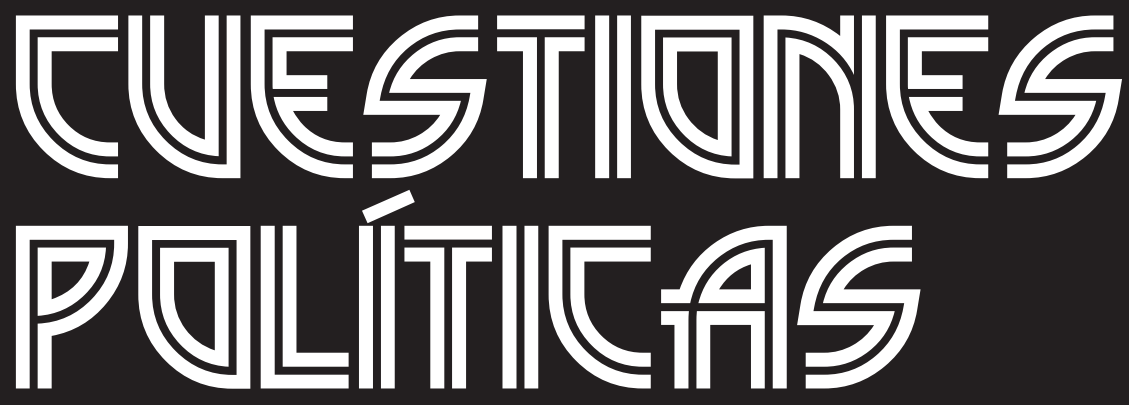

Instituto de Estudios Políticos y Derecho Público "Dr. Humberto J. La Roche' de la Facultad de Ciencias Jurídicas y Políticas de la Universidad del Zulia Maracaibo, Venezuela
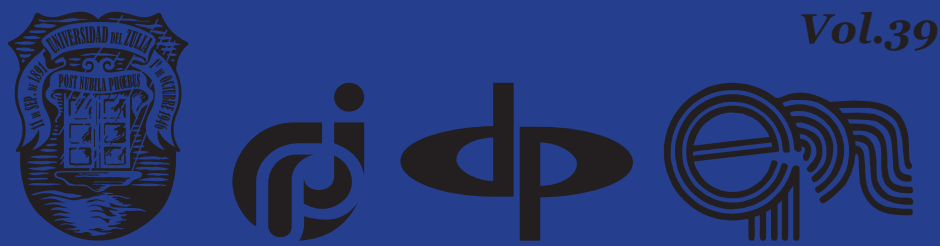


\title{
Problems of Efficiency of Legal Regulation of the Business Relation
}

\author{
DOI: https://doi.org/10.46398/cuestpol.3968.48
}

\begin{abstract}
Andrei Valerievich Mikhailov * Dmitrii Anatolievich Petrov **

Lilia Azatovna Sungatullina ${ }^{* * *}$

Robert Rinatovich Yzmailov ****

Anna Igorevna Kovshova *****
\end{abstract}

\section{Abstract}

The article is devoted to the analysis of the general legal problems of the regulation of economic relations in the Russian Federation. Problems that lead to insufficiently effective legal regulation are identified, while identifying directions for resolving them. The objective of this research was to review theoretical and practical problems of the effectiveness of the legal regulation of economic relations in the example of the Russian Federation, which makes it possible to draw some conclusions. To obtain the results, a set of scientific techniques and methods of study of phenomena and processes were applied, such as synthesis methods, comparative jurisprudence, as well as a formal legal method and an economic modelling method. The method of economic modelling made it possible to assess the extent to which and at what costs, the rule of law has produced the expected economic effect. It is concluded that the effectiveness of legal regulation is one of the essential legal categories and that the legislator is obliged to monitor existing legal standards for its effectiveness.

Keyword: Business law; legal problems; legal regulation in business matters; economic policy; Russian federation.

* Mikhailov Andrei Valerievich, Kazan Federal University, Ph.D., associate professor, department the business and energy law. ORCID ID: https://orcid.org/oooo-0oo3-2658-0122. Email: avm@ pravmail.ru

** Petrov Dmitrii Anatolievich, Saint Petersburg State University, associate professor, department of commercial law. ORCID ID: https://orcid.org/oooo-0o02-4262-9259. Email: PetrovDmitrii2020@ mail.ru

*** Lilia Azatovna Sungatullina, Kazan Federal University, Ph.D., associate professor, department of business law. ORCID ID: https://orcid.org/oooo-0002-4262-9259. Email: lilia.sungatullina@mail.ru

**** Robert Rinatovich Izmailov, Kazan Federal University, assistant, department of business and energy law. ORCID ID: https://orcid.org/oooo-0002-6927-1840. Email: izmailov.robert@mail.ru

***** Kovshova Anna Igorevna, Kazan Federal University, assistant, department of business and energy law. ORCID ID: https://orcid.org/oooo-0003-1804-5605. Email: ania881@mail.ru 


\section{Problemas de eficiencia de la regulación legal de la relación empresarial}

\section{Resumen}

El artículo está dedicado al análisis de los problemas legales generales de la regulación de las relaciones económicas en la Federación de Rusia. Se identifican los problemas que conducen a una regulación legal insuficientemente efectiva y, al mismo tiempo se indican las direcciones para resolverlos. El objetivo de esta investigación fue la revisión de problemas teóricos y prácticos de la efectividad de la regulación legal de las relaciones económicas en el ejemplo de la Federación de Rusia, lo que permite sacar algunas conclusiones. Para obtener los resultados se aplicaron un conjunto de técnicas científicas y métodos de estudio de fenómenos y procesos, tales como: métodos de síntesis, jurisprudencia comparada, así como un método legal formal y un método de modelización económica. El método de modelización económica permitió evaluar en qué medida y con qué costos el estado de derecho ha producido el efecto económico esperado. Se concluye que la efectividad de la regulación legal es una de las categorías legales esenciales y que el legislador está obligado a monitorear las normas legales existentes para su efectividad.

Palabras clave: Derecho empresarial; problemas legales; vigencia de la regulación legal en materia empresarial; política económica; federación rusa.

\section{Introduction}

Legal regulation, that is, the process of targeted impact of public authorities on certain social relations, can be more or less effective. By accepting the rules of law, taking specific actions to implement them, the state expects certain benefits and returns from the established rules of conduct. Quite often, for a variety of reasons, the legislator does not achieve the goals that were set before the adoption of the norm. Sometimes goals cannot be achieved for objective reasons, either because goals were set unattainable, or living conditions have changed significantly. But often, the norm does not achieve its goal because it was adopted without scientific, economic, and legal justification, without taking into account other legal norms. Sometimes, in order to achieve not the most economically important result, public authorities spend significant resources (labor, administrative) on the development, adoption, and implementation of a norm, while the same result can be achieved with much lower costs. The effectiveness of legal regulation seems to be one of the most significant indicators in jurisprudence. Ineffective regulation makes no sense in principle. It is 
Andrei Valerievich Mikhailov, Dmitrii Anatolievich Petrov, Lilia Azatovna Sungatullina, Robert Rinatovich Izmailov y Anna Igorevna Kovshova

760

Problems of Efficiency of Legal Regulation of the Business Relation

necessary to try by all means to contribute to the development of efficient, effective mechanisms of legal influence.

\section{Materials and Methods}

The methodological basis of the research presented in this article is a set of scientific techniques and methods of studying phenomena and processes - methods of analysis synthesis, comparative jurisprudence, as well as a formal legal method and a method of economic modeling. The use of these methods seems to be advisable for several reasons. The formal legal method allows us, on the basis of legislation, to form the applied conceptual apparatus, identify the signs and characteristics of the considered institutions of law. The comparative legal method allows us to study the possibility of implementing foreign experience in legal regulation.

\section{Research Results}

Both Soviet and Russian legal science has relatively little research on the effectiveness of branches of law, methods of legal regulation, or legal norms (Kudriavtsev et al., 1980). In philosophy and theory of law, efficiency (Latin efficientia - action, force, influence) is understood as the productivity of the use of resources in achieving a goal. It is quite difficult for legal regulation to assess productivity. It is very difficult to estimate the costs of adopting the norm. These are the costs of organizational work to change regulations, to conduct examinations, and a set of costs for the implementation of the norm, the creation and functioning of special bodies (persons) associated with the implementation of the norm. It is much easier to assess whether or not the goal of legal regulation has been achieved. Unfortunately, both Russian scientists and their colleagues in other countries give little attention to the effectiveness of the rule of law in their works, although there are works on the problems of the effectiveness of regulation in the economy (Spulber, 1989).

When the state regulates economic and business relations, the set goals may be very different. These are global, conceptual goals - ensuring market development, increasing GDP, improving the quality of life, and special goals - attracting investment, establishing a mechanism for protecting the rights of entrepreneurs, legal support for economic development, protecting consumer rights, ensuring tax collection, etc. The effectiveness of legal regulation is influenced by a variety of factors - from the political regime in the state to the legal and technical study of the adopted norms of law and the adequacy of the interpretation of the existing norms. The organization of the rules of law is also important - that is, what are the regulatory acts, branches of law, and other legal formations in the state (Dunne, 2015). 
What is important is the ratio in the legal system of the regulators of law laws and regulations, regulations, and customs.

In Russia and other post-Soviet states, an interesting legal feature has developed - the structural units of law are often formed based not on economic expediency, but on traditional ideas about the branches of law, formed in accordance with the generality of regulated relations. Traditional Russian jurisprudence denies many entities the status of a branch of law energy, sports, medicine, space, etc. Accordingly, it is believed that there is no point in these entities to adopt codes. Some states of the former USSR have already refused this approach - for example, Belarus has adopted the Banking, Electoral, and Education Codes, and a sports code was being developed.

In Russia, so far, many do not consider entrepreneurial law to be an independent branch and deny to accept the Entrepreneurial (or Commercial) Code as valid. This position leads to the fact that the norms governing relations with the participation of entrepreneurs are contained in a huge number of special laws, which often do not always unconditionally correspond to each other. But even if the Entrepreneurial Code appears in Russia, the rules governing entrepreneurial relations will still be contained in the tax, administrative, land, etc. legislation. Therefore, regardless of the way the issue of the organizational structure of the branches of law and the presence of codes will be resolved, the primary general condition for the effectiveness of the norms governing business relations is the synchronization of legal regulation, taking into account the intersectoral nature of the existing norms. It is necessary to ensure the consistency and complementarity of legal norms.

There are conditions which, if met, boost the effectiveness of legal regulation. Of course, there are various forms of effective legal regulation (Cross and Prentice, 2007); different countries have different economic and political situations. But in the most general form, such conditions include the following. This is the right choice for the purpose of regulation; real achievability of the goal; the correct choice of methods to achieve the set goal; the social value of the norm, its compliance with social realities and needs (the so-called macrosocial conditions); legal and technical quality of the norm, its adequate structure (the organic connection between the elements of a legal norm); availability, clarity of the norm for all subjects of law; correct informing of legal entities about the norm and the peculiarities of its application; ideological provision of the norm, determination of public authorities responsible for the implementation of the norm, and the establishment of their competencies; financing of measures to implement the rule of law.

We can state that not all conditions of effectiveness are associated with the actions of public authorities. Much depends on the specific subjects 
Andrei Valerievich Mikhailov, Dmitrii Anatolievich Petrov, Lilia Azatovna Sungatullina, Robert Rinatovich Izmailov y Anna I'gorevna Kovshova

of law and their legal culture. For the effectiveness of legal regulation in the economic sphere, it is important how free the economy of a particular country is, how high the level of development of civil society institutions and the level of corruption are, etc. It can also be noted that the nonmarket economic instruments used in totalitarian states can be considered ineffective in any case - as shown by world history in the XX century.

The former Soviet states, unfortunately, do not have sufficiently serious traditions of life in a free economy. The Revolution of 1917 in the Russian Empire led to a complete change in economic policy; for many years, a state-oriented type of economy based on state ownership was developing in the USSR. The population has developed an attitude towards the law as a tool that arbitrarily changes depending on the will of the ruling class. At the same time, the image of the state, responsible for absolutely everything, gradually developed in the minds of people. The state distributes incentives and restrictions of its own free will, and it is almost impossible for an ordinary person to influence this process. A peculiar attitude has also developed towards laws - if a law in some part does not seem attractive, it is not scary, it can be replaced. At first glance, this position does not appear negative. But in practice, it leads to a certain disrespect for the legislative act, to the emergence of a position that changing the law is a common and widely practiced phenomenon, which means that there is no particular need to carefully think over the adopted norms (which can, in any case, be changed).

For the economic sphere, this approach is extremely unpleasant. Constant changes in legislation lead to the fact that law enforcement officers do not have time to get used to the norms. As a result, there is a confusion of editions that are valid at different times. Practice does not have time to develop mechanisms of action in changing conditions; subjects do not always understand how to protect their rights. Accordingly, there are no important conditions for efficiency - clarity of the rule of law, correct information about the rule.

As an example of a constantly changing regulatory act, one can point to the most important for the Russian economy bankruptcy law (Heindler, 2018), adopted in 2002 and amended 109 times! Therefore, it is not surprising that for many years various lawyers have been stating the ineffectiveness of the bankruptcy law (Khodykin, 2013). Of course, constant change is far from the only reason. Bankruptcy legislation has two objectives - fair distribution of assets of persons declared bankrupt, and restoration of the solvency of persons who find themselves in a difficult economic situation. It is precise with the latter task that Russian bankruptcy law fails. But for the normal restoration of solvency, it is important to have not only well-thought-out legislation, but it is also important that the state of the economy allows for financial rescue measures. The general level of economic development 
is extremely important for the effectiveness of legal regulation - the more efficient the economy, the more effective the law, and vice versa.

Arguing about such a condition of efficiency as the determination of the authorities responsible for the implementation of the rule of law and the conduct of state policy in a particular area, we should note the following. For many years, the problem of eliminating redundant functions of the state has been discussed in Russia. This is a problem for many countries that are transitioning from a command-administrative economy to a market economy. And each country solves this problem in different ways. Unfortunately, in Russia to date, the superfluous functions of the state have not been completely removed. The list of unnecessary powers has been compiled by various structures on behalf of the President and the Government of Russia since 2000, but until the end, not a single project to eliminate excess powers has been implemented. This is hindered by the extremely large state apparatus - officials, apparently, cannot agree to radical reforms for fear of losing their place in the public service. At the beginning of 2019, the then-Chairman of the Government of Russia D.A. Medvedev announced a "regulatory guillotine" - to define and abolish all obsolete and unnecessary acts affecting the freedom of the economy. The fate of this next project is not yet clear.

It should be noted that many Russian state bodies have much more powers than similar structures in foreign countries. An example is the Federal Antimonopoly Service, which carries out 24 control functions apparently, this is a world record of control powers of one state body. Of course, Antimonopoly regulation is extremely important for the economy as it performs the most important functions (Whish and Bailey, 2015), especially in a country that is moving from state monopoly to the market. But too sweeping powers are hardly justified, the antimonopoly authorities of Russia initiate cases of violation of competition more than all the antimonopoly authorities in the world, and large-scale business is not the only one to be prosecuted. The environment of constant control, in our opinion, has a negative impact on business. Many entrepreneurs are afraid to start their own business, fear that the regulatory authorities will be able to prosecute for minor violations. Even the fact that economic entities have to spend their energy, time, and funds on communicating with inspectors does not add any advantages to the rating of the business climate.

Meanwhile, it is a favorable business investment climate that is one of the important conditions for the normal development of the economy and effective legal regulation.

Russia is definitely making attempts to improve its own investment legislation, but it is too early to talk about its integrity and consistency. Existing reform efforts are fragmented and not based on any well-thoughtout concept. Moreover, a similar characteristic can be given to the entire 
Andrei Valerievich Mikhailov, Dmitrii Anatolievich Petrov, Lilia Azatovna Sungatullina, Robert Rinatovich Izmailov y Anna I'gorevna Kovshova

complex of normative legal acts, on the basis of which the interaction of economic entities and public authorities is carried out. The legislation on special economic zones and other territories with a special regime for carrying out the entrepreneurial activity, on public-private partnership has not been sufficiently developed. Improvement of legal regulation in these areas is quite possible. It is necessary to abandon the "point" changes in legislation and go to the principles of improving legislation on the basis of a previously developed concept of development.

The investment legislation of Russia is currently represented by several acts. This is the law of Federal Law of July 9, 1999, No. 160-FZ "On foreign investments in the Russian Federation," Federal Law dated 02.08.2019 No. 259-FZ, "On attracting investments using investment platforms and on amending certain legislative acts of the Russian Federation"; Federal Law of April 1, 2020, No. 69-FZ "On the Protection and Promotion of Investment in the Russian Federation." This list shows that there is still no uniformity in regulation. In terms of the problems of the effectiveness of regulation, it is more promising to adopt general laws that apply to all subjects of the economy.

As a rule, developing countries create special investment laws or codes in seek to attract the maximum amount of foreign investment, create a most favored nation treatment for the investor. In most economically developed countries, there is no special investment legislation - it is believed that any investor should be protected by the rules of the law that are common to all. Ideally, Russia should also create conditions where a business is protected by general rules of law, general rules for investment, access to loans, protection of property rights, and without special investment legislation. For this, it is necessary, first of all, to clearly define one's own strategy for the development of investment legislation.

It's interesting to know that almost all investment legislation in Russia provides for the provision of benefits only to large investors. The latest adopted law - dated April 1, 2020 (Federal Law of April 1, 2020 No. 69FZ) - was created for industrial projects and does not take into account the specifics of infrastructure projects, which more often involve indirect effects for the economy. To get benefits from this law, a new investment project should be implemented, with 250 million to 5 billion rubles invested, depending on the field of activity. Thus, the majority of Russian entrepreneurs (according to the Chairman of the Accounts Chamber of the Russian Federation A.L. Kudrin, this is 95\% of all entrepreneurs) will never be able to use the provisions of this law. Investment legislation is often criticized in Russia, a decrease in the inflow of foreign investment is noted, but ineffective legislation itself contributes to the lack of investment. 


\section{Conclusion}

Our review of theoretical and practical problems of the effectiveness of legal regulation of economic relations on the example of the Russian Federation allows us to draw some conclusions. Efficiency is the most important legal category, legal acts and norms of law should be assessed in terms of their effectiveness. Different states have different legal regimes and different economic situations, but in the most general form, the set of factors that make legal regulation effective or ineffective is clear. For the economic sphere, the most important condition for efficiency is the synchronization of legal impact, i.e. complex legal regulation of economic relations, taking into account the mutual influence of the norms of various branches of law and a different legal nature. This is easier to achieve. By developing sufficiently large blocks of legislation, ideally codified acts, with a single terminology and with a comparable mechanism of legal impact. In addition, other conditions of effectiveness specified in this article must also be met. In addition, the law should not be changed often - constant changes in the rule of law have a negative impact on efficiency.

The conducted research allows us to systematize knowledge about the conditions for effective or ineffective legal regulation of economic relations. Meeting the indicated conditions will improve the quality of legal regulation. And we must remember that there is a close relationship between the level of economic development, the efficiency of the economy and the effectiveness of the law.

\section{Acknowledgments}

The work is performed according to the Russian Government Program of Competitive Growth of Kazan Federal University.

\section{Bibliographic References}

CROSS, Frank B; PRENTICE, Robert A. 2007. Law and Corporate Finance. Edward Elgar Publishing. Cheltenham, UK.

DUNNE, Niamh. 2015. Competition Law and Economic Regulation: Making and Managing Markets. Cambridge University Press. Cambridge, UK.

HEINDLER, Florian. 2018. Corporate and Unitary Legal Entities in Russia. Kluwer Law International BV. Amsterdam, Netherlands.

KHODYKIN, Roman. 2013. Arbitration law of Russia: practice and procedure. Juris Publishing, Inc. New York, USA. 
Andrei Valerievich Mikhailov, Dmitrii Anatolievich Petrov, Lilia Azatovna Sungatullina, Robert Rinatovich Izmailov y Anna I'gorevna Kovshova

KUDRYAVTSEV, VN; GLAZYRIN, VV; NIKITINSKII, VI; SAMOSHCHENKO, IS. 1980. The effectiveness of legal norms. - M: Iuridicheskaia Literatura. Saint Petersburg, Russia.

SPULBER, Daniel F. 1989. Regulation and Markets. MIT Press. Massachusetts, USA.

THE STATE DUMA. 1999. Federal law no. 160-fz of july 9, 1999 on foreign investment in the russian federation (with the Amendments and Additions of July 25, 2002, December 8, 2003, July 22, 2005, June 3, 2006, June 26, 2007, April 29, 2008).

THE STATE DUMA. 2019. Federal Law Of The Russian Federation of August 2, 2019 No. 259-FZ. (About investment attraction with use of investment platforms and about modification of separate legal acts of the Russian Federation). Available online. In: https://cis-legislation.com/document. fwx?rgn=117701. Consultation date: 14/05/2020.

THE STATE DUMA. 2020. Federal Law of April 1, 2020 No. 69-FZ "On the Protection and Promotion of Investment in the Russian Federation". Available online. In: http://publication.pravo.gov.ru/Document/ View/0001202004010030. Consultation date: 14/09/2020.

THE STATE DUMA. 2020. Federal Law of the Russian Federation of April 1, 2020 No. 69-FZ (About protection and encouragement of capital investments in the Russian Federation: as amended on 30-122020). Available online. In: https://cis-legislation.com/document. fwx?rgn=123396. Consultation date: 14/05/2020.

WHISH, Richard; BAILEY, David. 2015. Competition law. Oxford University Press. New York, USA. 

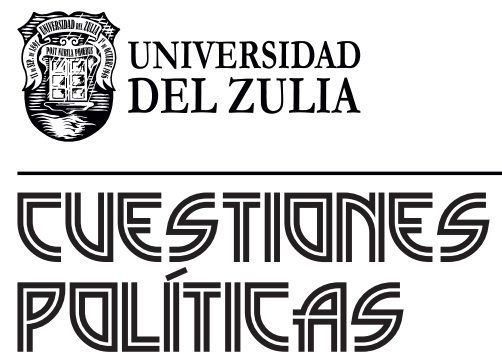

Vol.39 No 68

Esta revista fue editada en formato digital y publicada en enero de 2021, por el Fondo Editorial Serbiluz, Universidad del Zulia. Maracaibo-Venezuela 